CHAPTER 29

\title{
DUNE FORMATION AND STABILIZATION BY VEGETATION AND PLANTINGS
}

\author{
John H. Davis \\ Professor of Botany \\ University of Florıda \\ Gainesville, Florida
}

\begin{abstract}
Plantings of appropriate native and introduced plants and the management of extant vegetation are often very effective in promoting the development and maintenance of dunes that serve to protect shores against some types of erosion.
\end{abstract}

The importance of dunes as barriers, the formation of dunes, and the role of plants and vegetation are considered. The types of vegetation of the three zones usually present over dune fields are described, and the general management to maintain such vegetation is discussed.

Methods of making plantings on natural and artificial dunes by selecting, seeding, and transplanting the species that are most effective in building and stabillzing dunes are given.

Editor's note - This paper was a summary of the publication "Dune Formation and Stabilization by Vegetation and Plantings", by John H. Davis, Beach Erosion Board Technical Memorandum No. 101 , Oct. $1957,47 \mathrm{pp}$. The reader is referred to this publication for the complete paper. 